\title{
Nut and Kernel Characteristics of Exotic and Indigenous Almond (Prunus amygdalus Batsch.) Genotypes under Temperate Conditions of Kashmir Valley
}

\author{
Shabeena Majid ${ }^{2}$, Amit Kumar ${ }^{1}$, Bhinish Shakeel ${ }^{3}$, \\ Sabia Bashir ${ }^{2}$ and Shaheena Ahmad Nagoo ${ }^{4}$
}

${ }^{I}$ Division of Fruit Science, SKUAST-Kashmir, Shalimar Campus, Srinagar, J \& K, India

${ }^{2}$ Dryland Agricultural Research Station, Srinagar, SKUAST-Kashmir, J\& K, India

${ }^{3}$ Krishi Vigyan Kendra, Ganderbal, SKUAST-Kashmir, J\& K, India

${ }^{4}$ Temperate Sericulture Research Institute, Mirgund, Srinagar,

SKUAST-Kashmir, J\& K, India

*Corresponding author

\section{A B S T R A C T}

\section{Keywords}

Almond, Nut, Kernel, Exotic, Indigenous, Genotypes

Article Info

Accepted: 15 December 2019 Available Online: 20 January 2020
Investigations were carried out on nine almond varieties/selections (three exotic and six indigenous) to study their nut and kernel quality planted at experiment farm of Dryland Agriculture Research Station (DARS), SKUAST-Kashmir. Maximum nut weight (2.24 and $2.19 \mathrm{~g}$ ) and nut length (39.88 $\mathrm{mm}$ and $40.69 \mathrm{~mm}$ ) was recorded in Primorskij during $1^{\text {st }}$ and $2^{\text {nd }}$ year of study, respectively, however nut breadth was maximum in Waris $(20.42 \mathrm{~mm}$ and 20.17). Kernel weight was recorded highest Primorskij(1.29 g and $1.26 \mathrm{~g}$ ) along with kernel length (28.62 $\mathrm{mm}$ and $29.04 \mathrm{~mm}$ ) during both the years whereas minimum kernel breadth was registered in Waris $(12.68 \mathrm{~mm}$ and $12.44 \mathrm{~mm})$, respectively. Minimum values for nut weight $(1.11 \mathrm{~g}$ and $1.19 \mathrm{~g})$ and nut length $(26.37 \mathrm{~mm}$ and $25.27 \mathrm{~mm})$ was recorded in KD-05 and KD-06, respectively. Nut breadth $(17.00 \mathrm{~mm}$ and 16.86 $\mathrm{mm})$, kernel weight $(0.73 \mathrm{~g}$ and $0.80 \mathrm{~g})$, kernel length $(18.53 \mathrm{~mm}$ and $18.04 \mathrm{~mm})$ was recorded minimum in KD-03 whereas minimum kernel breadth was minimum in Waris $(10.85 \mathrm{~mm}$ and $10.53 \mathrm{~mm})$. Maximum shelling percentage $(57.58 \%$ and $52.05 \%$ ) was recorded in Primorskij during both the year of study. Primorskij had papery shell with intermediate kernel and shell colour. From the present investigation it is concluded that Primorskij performed best under temperate conditions of Kashmir.

\section{Introduction}

Almond (Prunus amygdalus Batsch) is an important nut crop of the world that is cultivated from the desert areas of Western China to the Mediterranean basin (Ladizinsky, 1999). It is one of the major and oldest tree-nut crops known to the mankind 
with wide-spread popularity throughout the world and is mainly grown under rainfed conditions in India with very low productivity (Sharma and Joolka, 2000). Almond kernels are concentrated sources of energy with a significant share of fat, protein and fibre. Fats are primarily non saturated, mostly oleinic and linoleic fatty acids. Non saturated fatty acid is an important in maintaining low cholesterol levels in the blood and significant amount of micro-nutrients (Aslanta et al., 2001). The kernel contains water (5.93-7.27 $\%)$, ash (8.03-8.13\%), oil (53.67-54.26\%), protein (23.03-23.98\%), total sugars (4.15$5.29 \%$ ), potassium (1546-1685 $\mathrm{mg} / 100 \mathrm{~g}$ ), phosphorous (253-259 mg/100 g), calcium (640-678 mg/100 g), magnesium (447-494 $\mathrm{mg} / 100 \mathrm{~g})$, copper $(24.30-25.80 \mathrm{ppm})$, zinc (76.33-80.50 ppm), iron (54.83-65.33 ppm) and manganese (37.67-37.83 ppm) (Aslanta et al., 2001, Adyin, 2003). In India, Jammu and Kashmir state ranks first with production of 10326 MT from an area of 5588 hectare in which Pulwama and Budgam districts are the leading producers (Anonymous, 2019). The commercial cultivation of almond on marginal lands under non-irrigated conditions could not spread much on account of intrinsic problems like spring frosts and hail storms during the blossoming time. However, still majority of the almond production comes from seedling trees of primitive population grown under rainfed conditions of Kashmir valley with different morphological and biological characteristics. In order to select varieties among these diverse types, characterization and evaluation of these genotypes is indispensable. Most of the commercial almonds cultivars grown throughout the world have been selected by chance from the diverse gene pool of almond seedlings (Kester et al., 1990). In varietal selection of almond the main objective is the introduction of superior seedlings with desirable traits like good growth habit, late bloom, frost and disease resistance, self- fertility and high yield. Introduction of few cultivars from abroad and selection released from SKUAST, attempts have been made to evaluate germplasm comprising various almond selections and cultivars so as to assess proper choice of varieties for almond growing belts of Kashmir.

\section{Materials and Methods}

\section{Experimental material and location}

The present investigations were carried out on nut and kernel quality characters of almond varieties planted in 1988 at Dryland Agriculture Research Station, (DARS),SKUAST-Kashmir, Jammu and Kashmir. The experimental farm is situated at a latitude of $34^{\circ} 05^{\prime} \mathrm{N}$ and longitude of $74^{\circ} 50^{\prime}$ $\mathrm{E}$ and at an altitude of $1640 \mathrm{~m}$ amsl with temperate region having cold conditions from November to February. The experimental was comprised of nine almond varieties viz. three exotic (Pranyaj, Merced, Primorskij) and six indigenous (Mukhdoom, Waris, Shalimar, KD-3, KD-5 and KD-6). Plants of uniform size and vigour were selected randomly and all the trees were kept under similar cultural practices to ensure uniform growth. The experiment was laid out in the randomized block design with four replications for each treatment.

\section{Observation recorded and data analysis}

Observations were recorded on nut and kernel characters. Nut weight and kernel weight of fifteen nuts was taken with the help of top pan balance, averaged value was worked out and expressed in grams.Nut (length and breadth) and kernel (length and breadth) was measured of fifteen nuts and kernels, averaged was worked out and expressed in mm. Kernel colour was visually observed and divided into classes (extremely light, light, intermediate, dark and extremely dark) whereas shell colour 
was visually observed and divided into(extremely light, light, intermediate, dark) as per descriptor (UPOV, 1985). Shell hardness was examined by force required to break the shell and grouped as (extremely hard, hard, intermediate, soft and papery).Shelling percentage was calculated by the formula.

Shelling percentage $=$

Kernel weight

Nut weight $\quad$ X 100

Organoleptic evaluation was done through sensory analysis with the panel of judges on the basis hedonic scale (Piggott, 1998). Data collected on various parameters for two consecutive years were computed and statistically analyzed as per the procedure given by Snedecor and Cochran (1994).

\section{Results and Discussion}

All the almond varieties and selections showed significant differences with respect to all the nut and kernel characters (Table 1 and Fig 1). Maximum nut weight in both the years was recorded in Primorskij (2.24 g and 2.19 g) which was statistically at par with Waris (2.12 g), Pranyaj(2.04 g) and Mukhdoom $(1.97 \mathrm{~g})$ in the first year whereas in the second year Primorskij was statistically at par with Mukhdoom (2.11 g), Pranyaj (2.10 g), Waris $(2.07 \mathrm{~g})$ and Merced (1.95 g) (Fig 1). Minimum nut weight in both the years was recorded in KD-5 (1.11 $\mathrm{g}$ and $1.19 \mathrm{~g}$, respectively). Primorskij (39.88 $\mathrm{mm}$ and $40.69 \mathrm{~mm}$ ) measured maximum nut length in both the years which was significantly higher among all the varieties however maximum breadth of nut was registered in Waris (20.42 $\mathrm{mm}$ and $20.17 \mathrm{~mm}$ ) which was significantly higher among all the varieties. Minimum nut length and nut breadth in both the year of study was measured in KD-6 $(26.37 \mathrm{~mm}$ and $25.27 \mathrm{~mm}$ ) and KD-3 (17.00 mm and 16.86 $\mathrm{mm})$. The maximum nut weight and nut size in Primorskij variety might be due to inherent characters of cultivars. Aydin (2003), Strikic et al., (2010) and Colic et al., (2012) also reported similar results for nut weight and nut size.

During both the year of study, highest kernel weight was observed in Primorskij(1.29 $\mathrm{g}$ and $1.26 \mathrm{~g})$ which was statistically at par with Pranyaj ( $1.15 \mathrm{~g}$ and $1.20 \mathrm{~g}$ ) whereas minimum kernel weight was recorded in KD-3 (0.73 g and $0.80 \mathrm{~g}$ ) (Fig 1). Significantly higher values was recorded by Primorskij $(28.62 \mathrm{~mm}$ and $29.04 \mathrm{~mm}$ ) for kernel length and by Waris (12.68 $\mathrm{mm}$ and $12.44 \mathrm{~mm}$ ) for kernel breadth as compared to all the varieties in both the years of study. Minimum kernel length and kernel length during both the years was recorded in KD-3 (18.53 $\mathrm{mm}$ and $18.04 \mathrm{~mm})$ and Shalimar (10.85 $\mathrm{mm}$ and $10.53 \mathrm{~mm})$, respectively. Waris almond registered dark colour of kernel whereas Merced and KD-5 had light kernel colour. Rest all the variation had intermediate in kernel colour. Earlier Karadeniz et al., (2003), Wang et al., (2004) and Kumar and Ahmed (2015) also reported similar results for kernel characters however variation for different nut and kernel characters might be due to the genetic makeup of the varieties and prevailing environmental conditions of area.

Shelling percentage and organoleptic evaluation depicts significant results among all the varieties (Table 2). Highest shelling percentage was recorded in Primorskij (57.58 $\%)$ which was statistically at par with Pranyaj $(57.52 \%)$ in the first year however in the second year Merced (54.05\%) was significantly higher in shelling percentage among all the varieties. In both the years, lowest shelling percentage was recorded in 
KD-3 (28.74\% and $33.61 \%)$. In the earlier studies, Kumar and Sharma (2005) also reported 53.79 per cent of kernel recovery in Telangi Selection from Kinnaur district of Himachal Pradesh. Present results are in accordance with the earlier results reported by Kaska et al., (1994), Ak et al., 2005 with respect to shelling percentage. Among different almond varieties/selections studied Merced, Primorskij and Shalimar had papery shell whereas Pranyaj and Waris had soft shell. Mukhdoom and KD-5 had semi-soft shell however KD-3 and KD-6 were hard in shelling. Soft, moderate and hard type of shell was also reported by earlier workers (Nieddu et al., 1994, Talhouk et al., 2000, Sepahvand et al., 2015). Light (Mukhdoom, Waris and Shalimar), intermediate (Merced and Primorskij, KD-3, KD-5 and KD-6) and dark (Pranyaj) shell colour was obtained in different almond varieties/selections.

Table.1 Nut and kernel characters of exotic and indigenous almond genotypes

\begin{tabular}{|c|c|c|c|c|c|c|c|c|c|}
\hline \multirow[t]{3}{*}{ Genotypes } & \multicolumn{4}{|c|}{ Nut size (mm) } & \multicolumn{4}{|c|}{ Kernel size (mm) } & \multirow{3}{*}{$\begin{array}{l}\text { Kernel } \\
\text { colour }\end{array}$} \\
\hline & \multicolumn{2}{|c|}{ Length } & \multicolumn{2}{|c|}{ Breadth } & \multicolumn{2}{|c|}{ Length } & \multicolumn{2}{|c|}{ Breadth } & \\
\hline & $\begin{array}{c}1^{\text {st }} \\
\text { year }\end{array}$ & $\begin{array}{l}2^{\text {nd }} \\
\text { year }\end{array}$ & $\begin{array}{c}1^{\text {st }} \\
\text { year }\end{array}$ & $\begin{array}{l}2^{\text {nd }} \\
\text { year }\end{array}$ & $\begin{array}{c}1^{\text {st }} \\
\text { year }\end{array}$ & $\begin{array}{l}2^{\text {nd }} \\
\text { year }\end{array}$ & $\begin{array}{c}1^{\text {st }} \\
\text { year }\end{array}$ & $\begin{array}{l}2^{\text {nd }} \\
\text { year }\end{array}$ & \\
\hline Pranyaj & 36.88 & 37.66 & 19.50 & 19.26 & 26.86 & 27.00 & 12.11 & 11.97 & Intermediate \\
\hline Mer & 35.97 & 35.00 & 18.00 & 18.24 & 26.65 & 26.26 & 11.60 & 11.34 & \\
\hline Prin & 39.88 & 40.69 & 18.79 & 18.97 & 28.62 & 29.04 & 11.80 & 11.63 & diate \\
\hline Muk & 30.32 & 31.24 & 19.44 & 19.58 & 22.15 & 23.00 & 10.94 & 11.18 & Intel \\
\hline Waris & 32.40 & 33.00 & 20.42 & 20.17 & 22.77 & 23.01 & 12.68 & 12.44 & \\
\hline Shali & 34.59 & 35.72 & 17.14 & 17.50 & 25.77 & 26.30 & 10.85 & 10.53 & Interm \\
\hline KD-3 & 26.44 & 26.11 & 17.00 & 16.86 & 18.53 & 18.04 & 11.4 & 11.12 & Intermediate \\
\hline KD-5 & 26.80 & 27.00 & 17.8 & 17.90 & 19.12 & 18.12 & 10.98 & 11.02 & \\
\hline KD-6 & 26.37 & 25.27 & 19.11 & 19.00 & 19.53 & 20.07 & 11.24 & 11.39 & Intermediate \\
\hline $\mathrm{CD}_{0.05}$ & 0.54 & 1.87 & 0.47 & 0.56 & 0.18 & 0.24 & 0.28 & 0.18 & \\
\hline
\end{tabular}

Table.2 Shell characters and organoleptic evaluation of exotic and indigenous almond genotypes

\begin{tabular}{|c|c|c|c|c|c|c|}
\hline \multirow[t]{2}{*}{ Genotypes } & \multicolumn{2}{|c|}{ Shelling percentage } & \multirow[t]{2}{*}{$\begin{array}{c}\text { Shell } \\
\text { hardness }\end{array}$} & \multirow[t]{2}{*}{ Shell colour } & \multicolumn{2}{|c|}{$\begin{array}{c}\text { Organoleptic } \\
\text { evaluation }\end{array}$} \\
\hline & $1^{\text {st }}$ year & $2^{\text {nd }}$ year & & & $1^{\text {st }}$ year & $2^{\text {nd }}$ year \\
\hline Pranyaj & 57.52 & 51.06 & Soft & Dark & 7.0 & 8.0 \\
\hline Merced & 49.27 & 54.05 & Papery & Intermediate & 8.0 & 8.0 \\
\hline Primorskij & 57.58 & 52.05 & Papery & Intermediate & 7.0 & 7.0 \\
\hline Mukhdoom & 39.59 & 45.07 & Semi-soft & Light & 9.0 & 9.0 \\
\hline Waris & 49.05 & 47.50 & Soft & Light & 8.0 & 7.0 \\
\hline Shalimar & 48.60 & 50.27 & Papery & Light & 9.5 & 9.5 \\
\hline KD-3 & 28.74 & 33.61 & Hard & Intermediate & 5.0 & 4.0 \\
\hline KD-5 & 36.36 & 39.54 & Semi-soft & Intermediate & 3.0 & 4.0 \\
\hline KD-6 & 38.05 & 48.12 & Hard & Intermediate & 5.0 & 6.0 \\
\hline $\mathrm{CD}_{0.05}$ & 0.64 & 0.32 & & & 0.39 & 0.05 \\
\hline
\end{tabular}


Fig.1 Nut weight and kernel weight of exotic and indigenous almond genotypes

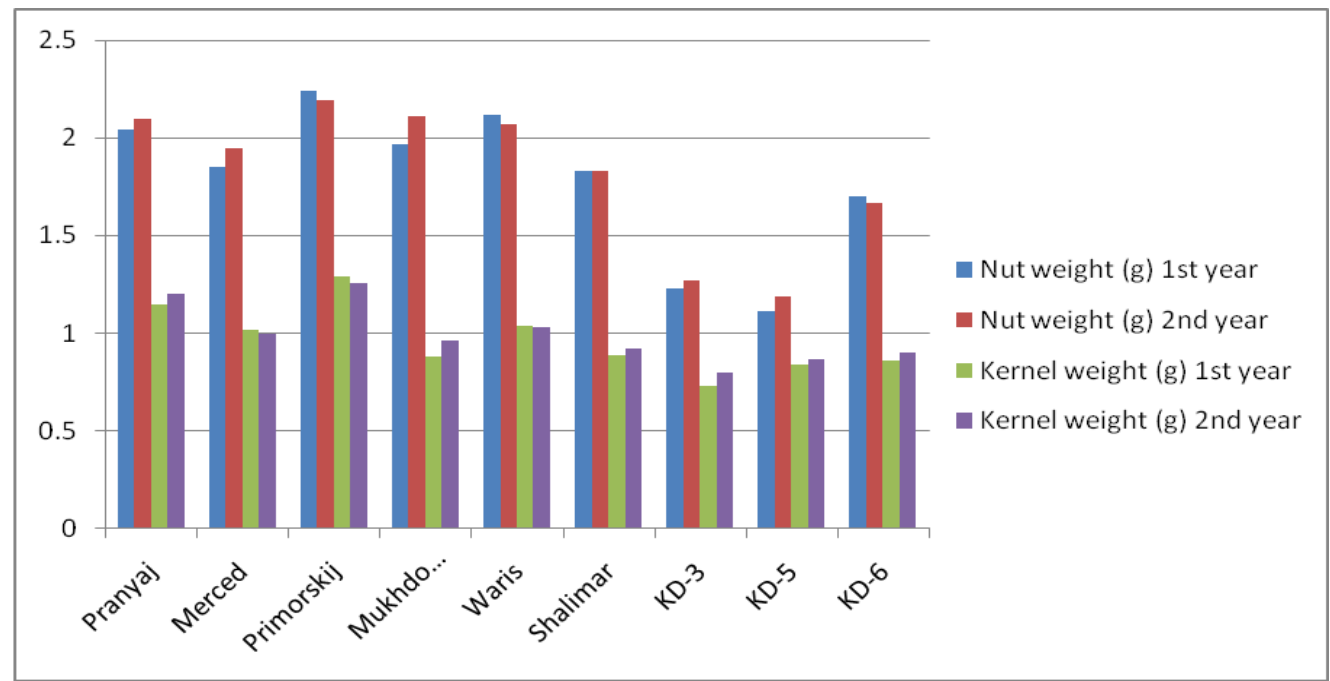

Based upon organoleptic evaluation, Shalimar (9.5 and 9.5) got significantly higher number in both the year followed by Mukhdoom (9.0 and 9.0) and Merced (8.0 and 8.0), however minimum number for organoleptic evaluation was scored by KD-5 (3.0 and 4.0) during both the years, respectively.

From the above discussion, it is concluded that Primorskij performed best under temperate conditions of Kashmir for nut weight, nut length, kernel weight, kernel length, shelling percentage and shell hardness followed by Pranyaj.

\section{References}

Ak, B.E., Kuzdere, H. and Kaska, N. 2005. An investigation on phenological and pomological traits of some almond cultivars grown at Ceylanpinar State farm in Turkey. Options Mediterraneennes, 63: 43-48.

Anonymous, 2019. Area and Production of Fruit Crops. Department of Horticulture, Jammu and Kashmir, pp $1-2$

Aslanta, R., Guleryuz, M. and Tarun M. 2001. Some chemical contents of selected almond (Prunus amygdalus Batsch) types. In: Be, A.K. (ed.). Seminar on pistachios and almonds, Cahiers Options Mediterraneennes, 56: 347-350

Aydin, C. 2003. Physical properties of almond nut and kernel. Journal of Food Engineering 60(3): 315-320.

Colic, S., Rakonjac, V., Zec, G., Nicoli, D. and Aksi, F.M. 2012. Morphological and biochemical evaluation of selected almond (Prunus dulcis mill.) genotypes in North Serbia. Turkish Journal of Agriculture Forestry, 36: 429-438

Karadeniz, T., Kazankaya, A. and Yarilgac, T. 2003. Determination of the pomological characteristics of Almonds (PrunusamygdalusBatsch.) grown in Malatya (Turkey). Agriculture Scientific and Professional Review 9(1): 42-45.

Kaska, N., Kuden, A. and Kuden, A.B. 1994. Almond production in Southeast Anatolia. Acta Horticulturae 373: 253258.

Kester, D.E. and Gradziel, T.M. 1996. Almonds In: Janick, J. and Moore, J.N. (eds.). Fruit Breeding, Vol III: Nuts. John Wiley and Sons, New York, pp. 196.

Kester, D.E., Gradziel, T.M. and Grasselly, C. 
1990. Almond p. 701-758. In: Moore, J.N. and JR Jr Ballington (eds). Genetic resources of temperature fruit and nut crops. Institute of Horticulture Sciences Wageningin. The Netherlands.

Kumar, D. and Ahmed, N. 2015.Morphological and pomological evaluation of almond (Prunus dulcis) cultivars under North-West Himalayan region of India. International Journal of Horticulture 5(15): 1-6

Kumar, K. and Sharma, S.D. 2005. Selfcompatible indigenous almond selection: characterization and assessment. ActaHorticulturae 696: 6568.

Ladizinsky, G. On the origin of almond. Genetic Resources and Crop Evolution. 46: 143-147

Nieddu, G., Chesso, I., Pala, M. and Lovicu, G. 1994. Evaluation of almond germplasm in Sardinia: further observations. Acta Horticulturae 373: 135-139.

Piggott, J.R. 1998. Sensory analysis of foods. Elsevier Applied Sciences, London.

Sepahvand, E., Khadivi-Khub, A., Ali, M. and Fallahi, E. 2015.Evaluation of an almond collection using morphological variables to choose superior trees. Fruits 70: 53-59.

Sharma, M.K. and Joolka, N.K.2000.Effect of soil and foliar application of nitrogen on the leaf nutrient status of almond (Prunus amygdalus Batsch.). J. Hort. Sci. 29(3/4): 191-192.

Snedecor, G.W. and Cochran, W.G. 1994. Statistical Method. English edition. First East-West Press edition, New Delhi pp 503

Strikic, F., Radunic, M., Paskovic, I., Klepo, T. and Cmelik, Z. 2010. Morphological and pomological traits of almond phenotypes (Amygdalus communis L.) isolated from their natural population. African Journal of Biotechnology, 9(4): 454-460

Talhouk, S.N., Lubani, R.T., Baalbaki, R., Zurayk, R., Al-Khatib, A., Parmaksizian, L. and Jaradat, A.A. 2000.Phenotypic diversity and morphological characterization of Prunus amyglalus L. species in Lebanon. Genetic Resources and Crop Evolution 47(1): 93-104.

UPOV. 1985. Almond Descriptors (d'noyer). General information: International Union for the Protection of New Varieties of Plants/TG/125/1 (Prog.) Geneva, Switzerland.

Wang, J.Y., Han, H. and Zhang, Y. 2004. Four promising almond cultivars bred in China and their cultural techniques. China Fruits 3: 48-49.

\section{How to cite this article:}

Shabeena Majid, Amit Kumar, Bhinish Shakeel, Sabia Bashir and Shaheena Ahmad Nagoo. 2020. Nut and Kernel Characteristics of Exotic and Indigenous Almond (Prunus amygdalus Batsch.) Genotypes under Temperate Conditions of Kashmir Valley. Int.J.Curr.Microbiol.App.Sci. 9(01): 1914-1919. doi: https://doi.org/10.20546/ijcmas.2020.901.214 